\title{
Commentary: Vascular conduits modified by gene therapy
}

\author{
Ming-Sing Si, MD
}

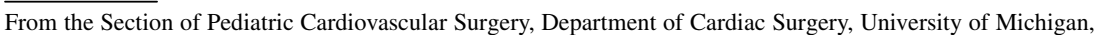
Ann Arbor, Mich.

Disclosures: Author has nothing to disclose with regard to commercial support.

Received for publication Oct 8, 2018; accepted for publication Oct 8, 2018; available ahead of print Nov 13, 2018. Address for reprints: Ming-Sing Si, MD, 11-735 C.S. Mott Children's Hospital SPC 4204, 1540 E. Hospital Drive, Ann Arbor, MI 48109-4204 (E-mail: mingsing@umich.edu).

J Thorac Cardiovasc Surg 2019;157:2254-5

$0022-5223 / \$ 36.00$

Copyright (C) 2018 Published by Elsevier Inc. on behalf of The American Association for Thoracic Surgery

https://doi.org/10.1016/j.jtcvs.2018.10.023

Coronary artery disease is prevalent in developed countries, and coronary artery bypass is one of the more common surgical procedures performed in the United States. Although the left internal thoracic to the left anterior descending coronary artery bypass has yielded an established survival advantage, the use of autologous saphenous vein grafts is required if the left internal thoracic artery or other arterial grafts are not available. Saphenous vein grafts fail at up to $25 \%$ after 1 year because of progressive obstruction secondary to initial hyperplasia from vascular smooth muscle cell proliferation and migration. ${ }^{1,2}$ It is postulated that this proliferative response is secondary to placing a vein (usually in a low-pressure environment) into the higher pressure of the arterial system, which causes excessive distention. ${ }^{3}$ The resulting obstructions are not amenable to durable medical treatment, and this has been an area of research for approximately half a century.

Gene therapy, or the genetic modification of cells to modify their phenotype, has been applied to saphenous vein grafts. Early efforts of gene therapy used the transfer of exogenous DNA or RNA via viruses, plasmids, electroporation, liposomes, or external pressure. However, the efficiency of gene transfer of some of these methods is very low, and those that are efficient have significant safety concerns. A large trial evaluating an E2F transcription factor decoy that was delivered by a pressure-based device was not shown to be effective, underscoring the difficulty in this approach. ${ }^{4}$

MicroRNAs (miRNAs) are small RNAs that can modify gene expression in a post-translational manner and have been suggested as therapeutic targets for disease, thereby expanding the repertoire of gene therapy. ${ }^{5}$ A number of miRNAs have been discovered to be important in the process of vein graft neointimal hyperplasia in vivo..$^{6-8}$ In this issue of the Journal, Nishio and colleagues ${ }^{9}$ describe a new gene therapy approach to combat vein graft neointimal hyperplasia after placement into the arterial system. Their therapeutic strategy has 2 components. First, they use miRNA-145 as their biologically active ingredient to impart

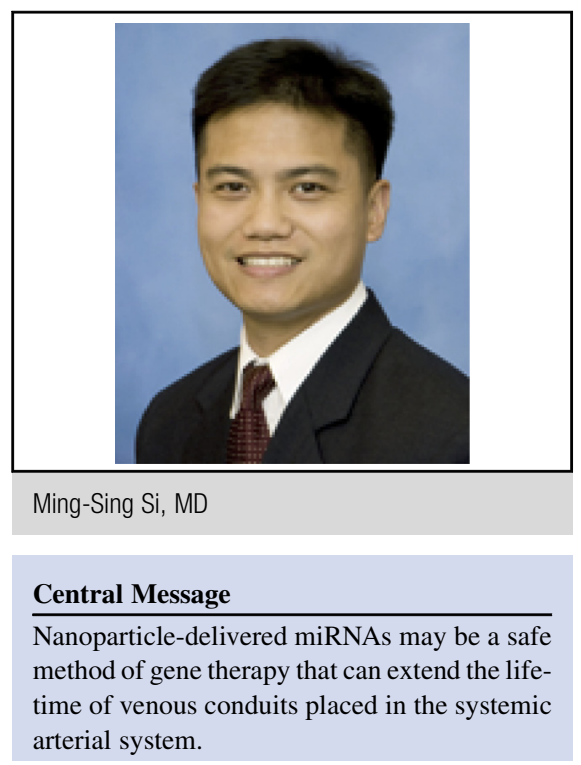

See Article page 2242. gene therapy. The use of miRNA-145 builds on their prior work with this miRNA, in which they used a rabbit model of interposition grafting using jugular vein transduced by miRNA-145 encoding plasmids. ${ }^{8}$ MiRNA-145 has been shown to modify the vascular smooth muscle cell fate and phenotype. ${ }^{10}$ The second component of their strategy was to use poly(lactic-co-glycolic acid) nanoparticles (PLGA NPs) to deliver the miR-145. Cells can endocytose the PLGA NPs, effectively delivering their payload of miR145 to the interior of the cells. How the miRNA-145 leaves the endocytic vesicles to enter the cytoplasm where they combine with an active RNA-induced silencing complex to target mRNA is unclear. These investigators denuded the endothelium of rabbit jugular veins with a Fogarty balloon, harvested and soaked them in solution containing miR-145-loaded PLGA NPs, implanted them as an interposition graft in the ipsilateral carotid artery, and explanted them after 2 weeks. They found that treatment with miRNA-145-loaded PLGA NPs significantly reduced vein graft neointimal hyperplasia. Furthermore, treatment decreased the number of proliferating cells and the levels of the inflammatory marker CD40.

This work represents a tangible step of their gene therapy approach toward clinical translation. By using miRNAs and a safe delivery method to impart therapeutic changes to gene expression, these investigators have avoided the 
concerns of plasmid and viral-based gene therapy methods. Critically, future work will have to establish the durability of this single treatment and possibly demonstrate its efficacy in a long-term nonhuman primate model. Perhaps the delivery of a cocktail of other miRNAs and even arterial-specific vascular smooth muscle cell miRNAs may yield the most durable approach. ${ }^{11}$

\section{References}

1. Harskamp RE, Lopes RD, Baisden CE, de Winter RJ, Alexander JH. Saphenous vein graft failure after coronary artery bypass surgery: pathophysiology, management, and future directions. Ann Surg. 2013;257: 824-33.

2. Hess CN, Lopes RD, Gibson CM, Hager R, Wojdyla DM, Englum BR, et al. Saphenous vein graft failure after coronary artery bypass surgery: insights from PREVENT IV. Circulation. 2014;130:1445-51.

3. Raja SG, Haider Z, Ahmad M, Zaman H. Saphenous vein grafts: to use or not to use? Heart Lung Circ. 2004;13:403-9.

4. Alexander JH, Hafley G, Harrington RA, Peterson ED, Ferguson TB Jr, Lorenz TJ, et al. Efficacy and safety of edifoligide, an E2F transcription factor decoy, for prevention of vein graft failure following coronary artery bypass graft surgery: PREVENT IV: a randomized controlled trial. JAMA 2005;294:2446-54.

5. Jeyaseelan K, Herath WB, Armugam A. MicroRNAs as therapeutic targets in human diseases. Expert Opin Ther Targets. 2007;11:1119-29.

6. Wang XW, Zhang C, Lee KC, He XJ, Lu ZQ, Huang C, et al. Adenovirus-mediated gene transfer of microRNA-21 sponge inhibits neointimal hyperplasia in rat vein grafts. Int J Biol Sci. 2017;13:1309-19.

7. Qu Q, Bing W, Meng X, Xi J, Bai X, Liu Q, et al. Upregulation of miR-126-3p promotes human saphenous vein endothelial cell proliferation in vitro and prevents vein graft neointimal formation ex vivo and in vivo. Oncotarget. 2017;8: 106790-806.

8. Ohnaka M, Marui A, Yamahara K, Minakata K, Yamazaki K, Kumagai M, et al. Effect of microRNA-145 to prevent vein graft disease in rabbits by regulation of smooth muscle cell phenotype. J Thorac Cardiovasc Surg. 2014;148:676-82.e672.

9. Nishio H, Masumoto H, Sakamoto K, Yamazaki K, Ikeda T, Minatoya K. MicroRNA-145-loaded poly(lactic-co-glycolic acid) nanoparticles attenuatevenous intimal hyperplasia in a rabbit model. J Thorac Cardiovasc Surg. 2019;157: 2242-51.

10. Cordes KR, Sheehy NT, White MP, Berry EC, Morton SU, Muth AN, et al. miR145 and miR-143 regulate smooth muscle cell fate and plasticity. Nature. 2009; 460:705-10.

11. Nabzdyk CS, Pradhan-Nabzdyk L, LoGerfo FW. RNAi therapy to the wall of arteries and veins: anatomical, physiologic, and pharmacological considerations. $J$ Transl Med. 2017;15:164. 